\title{
BISERICA ŞI EDUCAŢIA TINERILOR PENTRU VIAŢA VEŞNICĂ
}

Florin Botezan *

\begin{abstract}
Youth education in Church represents more than transmitting theoretical knowledge about God, it is an education towards salvation which shares to the people the liberating truths of faith in order to know the "love of Christ that surpasses knowledge(Ephesians 3, 19), calling them to repentance, to put on "the new man created to be like God in true righteousness and holiness"(Ephesians 4, 24), to fill themselves, in the power of the Holy Spirit, with "the fullness of God(Ephesians 3, 19). It is an education of the Church and in the Church that lead us towards the existential knowledge of God, which is eternal life (John 17, 3) and which implies our transformation, our coming "unto a perfect man, unto the measure of the stature of the fullness of Christ(Ephesians 4, 13). The educational ideal of the Christian Orthodox education is that men to become saints, at the resemblance to God.
\end{abstract}

Keywords: youth education, Christian, Church, eternal life, saint.

\section{Introducere}

Omul vine în lume ca o făptură nedesăvârşită ce are nevoie de creştere, de hrănire, de cultivare, adică de educaţie, termenul de educaţie provenind din substantivul latin educatiocare înseamnă tocmai creştere, hrănire, cultivare. De aceea educaţia este prezentă în toate societăţile omeneşti, însă forma concretă în care ea se realizează şi finalitatea vizată este determinată în mod decisiv de concepţia despre lume, om şi viaţă care îi stă la bază. Finalitatea educaţiei este exprimată de idealul educativ care, de-a lungul istoriei, cunoaşte o tipologie largă şi diversă. În condiţiile secularizării actuale, idealul educativ al societăţilor numite civile şi democratice

\footnotetext{
* $\mathrm{PhD}$, Teacher at "Saint Simion Stefan Ortodox Theological Seminary in Alba Iulia, Romania.
} 
(între care se înscrie şi societatea românească contemporană) se rezumă la viaţa prezentă a omului. Definită ca un fenomen social fundamental de transmitere a experienţei de viaţă a generaţiilor adulte şi a culturii către generaţiile de copii şi tineri, abilitării pentru integrarea lor în societate" , educaţia tinerilor este în mare parte asumată de statul secular şi realizată în mod direct prin sistemul de învăţământ şi, indirect, prin întreaga cultură la care au acces tinerii, inclusiv prin mass-media.

Dumnezeu ne descoperă însă faptul minunat că omul este veşnic şi că această viaţă nu este decât o etapă pregătitoare pentru veşnicie, o etapă în care omul este chemat să crească cultivând în el cele ale veşniciei pentru a dobândi viaţa cea veşnică în Împărăţia lui Dumnezeu. Întreaga relaţie a omului cu Dumnezeu poate fi privită astfel ca o lucrare de educare a omului de către Dumnezeu: în marea Sa iubire de oameni, Dumnezeu se străduieşte să-1 educe pe om spre a ajunge la împlinirea potenţialităţilor care au fost sădite în el, adică spre a înainta de la chipul lui Dumnezeu după care a fost creat (Fac. 1, 26-27) la asemănarea cu El, la sfinţenie.

\section{Educarea omului de către Dumnezeu până la întruparea lui Hristos}

Prin însuşi faptul că omul este creat după chipul lui Dumnezeu spre a ajunge la asemănarea cu El, Dumnezeu îl defineşte pe om ca fiind o fiinţă de educat ${ }^{2}$.

Această lucrare de educare a început chiar înainte de facerea omului, prin crearea lumii. Omul a fost creat la urmă, ca un împărat al creaţiei, şi toate făpturile create mai înainte sunt cuvinte plasticizate prin care Dumnezeu îi vorbeşte omului despre Sine:

${ }^{1}$ Dicţionarul explicativ al limbii române, București, Edit. Univers Enciclopedic Gold, 2009, http://dexonline.ro/definiţie/educație.

2 Ernst Lichtenstein, Bildungsgeschichtlichen Perspektiven. Glaube und Bildung als geschichtliche Begegnung, Ratingen bei Dusseldorf, 1962, p. 26, apud Cristina Benga, Idealul educaţional în pedagogia creştină. Clement de Alexandria, Sfântul Ioan Gură de Aur, Fericitul Augustin, prefaţă de Viorel Nicolescu, Bucureşti, Edit. Sophia, 2009, p. 137. 
Cerurile spun slava lui Dumnezeu şi facerea mâinilor Lui o vesteşte tăria (Ps. 18, 19). Sfântul Apostol Pavel subliniază în acelaşi sens: Cele nevăzute ale Lui se văd de la facerea lumii, înţelegându-se din făpturi, adică veşnica Lui putere şi dumnezeire (Rom. 1, 20). Comentând descrierea biblică a creaţiei lumii, Sfântul Ioan Gură de Aur arată:

\begin{abstract}
„Ai văzut că Scriptura spune că Dumnezeu, la fiecare creaţie, a lăudat ceea ce a creat? Aceasta pentru ca mai târziu, omenirea, instruită de aceste cuvinte, să se urce cu mintea de la creaturi la Creator. Dacă făpturile lui Dumnezeu sunt de aşa fel încât depăşesc firea omenească şi nimeni nu le poate lăuda după vrednicie, ce mai poţi spune de Creatorul lor?"3.
\end{abstract}

Aşadar, aşa cum au remarcat Sfinţii Părinţi ai Bisericii, întreaga creaţie este menită să-l ajute pe om să-şi înalţe mintea spre Dumnezeu, înţelegând limitele făpturii şi măreţia menirii sale de a ajunge asemenea cu Creatorul.

Aşezându-l pe om în rai, Dumnezeu continuă lucrarea de educare a acestuia dându-i porunca de a nu mânca din pomul cunoştinţei binelui şi al răului şi avertizându-l că neascultarea îi va aduce moartea. Dar omul calcă această poruncă plecând urechea la ispita diavolului care îi induce mai întâi neîncrederea în Dumnezeu şi apoi îi sugerează că prin neascultare se poate ajunge direct şi fără efort la asemănarea cu Dumnezeu: Nu, nu veţi muri! Dar Dumnezeu ştie că în ziua în care veţi mânca din el vi se vor deschide ochii şi veţi fi ca Dumnezeu, cunoscând binele şi răul (Fac. 3, 4-5). Dorind să ajungă asemenea cu Dumnezeu dar fără Dumnezeu, omul se desparte de Dumnezeu şi moare sufleteşte căzând din har.

Dumnezeu nu îşi întoarce însă faţa de la făptura Sa ci, după ce încearcă în zadar să provoace pocăinţa lui Adam şi a Evei (Fac. 3, 8-21), începe o nouă lucrare pedagogică pentru ca omul să-şi revină

\footnotetext{
${ }^{3}$ Sfântul Ioan Gură de Aur, Omilii la Facere, V, V, în „Scrieri”, partea întâi, traducere, introducere, indici şi note de D. Fecioru, col. „Părinţi şi Scriitori Bisericeşti”, vol. 21, Bucureşti, Edit. Institutului Biblic şi de Misiune al Bisericii Ortodoxe Române, p. 73.
} 
în fire. Alungându-l pe om din rai, Dumnezeu îngăduie ca suferinţa şi moartea să se abată asupra omului pentru ca acesta să înţeleagă cât de nefirească este despărţirea de Dumnezeu şi să se întoarcă prin pocăinţă la El.

$\mathrm{Cu}$ toate că omenirea se depărtează tot mai mult de Dumnezeu adâncindu-se în rău, Dumnezeu grăieşte în continuare oamenilor în care îşi poate găsi parteneri de dialog şi care îi primesc cuvântul. Apoi, pe temeiul credinţei lui Avraam, îşi alege poporul format din urmaşii acestuia, poporul evreu, ca popor al său menit să păstreze dreapta credinţă şi ca din mijlocul lui să se nască Hristos, Mântuitorul lumii. Acestui popor îi grăieşte prin prooroci, îi descoperă Legea dumnezeiască şi încearcă să-l educe. După cum s-a remarcat, autorii Vechiului Testament L-au zugrăvit pe Creator ca fiind puternic şi milos în acelaşi timp, interesat de fiinţa umană creată, preocupat de educarea omului. Iahve, ca educator, Îşi iubeşte poporul şi caută ca, prin chemarea $\mathrm{Sa}$, să-l conducă către bine, certându-1 atunci când este nevoie (cf. Lev. 26, 18; 28) sau îndemnându-1 la pocăinţă (cf. Ier. 2, 19)." În întregul Său demers educativ, Dumnezeu îi pune în faţă poporului său idealul sfinţeniei ca asemănare cu El: „Vorbeşte la toată obştea fiilor lui Israel şi le zi: Fiţi sfinţi, că Eu, Domnul Dumnezeul vostru, sunt sfânt" (Lev. 19, 2). Făptura omenească, pervertită de păcat, se dovedeşte însă neputincioasă în a ajunge la asemănarea cu Dumnezeu prin puterea proprie şi a fost nevoie, aşa cum arată o expresie consacrată a Sfinţilor Părinţi, ca Însuşi Dumnezeu să se facă om pentru ca omul să se facă dumnezeu prin har.

${ }^{4}$ Cristina Benga, op. cit., p. 28. 


\section{Iisus Hristos, Pedagogul suprem}

Fiul lui Dumnezeu S-a întrupat făcând-se Om şi rămânând în veci Dumnezeu-Om. Astfel Dumnezeu a dat omului cel mai mare lucru pe care putea să-1 dea. Mărunta fiinţă omenească a încăput pe Dumnezeu Cel neîncăput şi nemărginit, Dumnezeu rămânând Dumnezeu şi trupul rămânând trup în persoana Dumnezeu-Omului Iisus Hristos, Dumnezeu desăvârşit şi om desăvârşit. Aceasta face ca Dumnezeu-Omul să fie cea mai enigmatică fiinţă din toate lumile omeneşti ${ }^{5}$. Este cea mai mare noutate din toate noutăţile, singurul nou sub soare (Eccl. 1, 9-10), prin care se arată puterea infinită a lui Dumnezeu"6.

Fiul lui Dumnezeu, Care S-a întrupat pentru noi, este numit de Sfầntul Apostol şi Evanghelist Ioan, Logosul sau Cuvântul. Cuvântul, în înţelesul său primordial, reprezintă manifestarea unei persoane către alta în vederea stabilirii unei comuniuni, este expresia intenţionalităţii spre comuniune care caracterizează persoana. În acelaşi timp are funcţia de descoperitor al realităţii, al sensului ei ${ }^{7}$. Fiul lui Dumnezeu este numit Cuvânt, Logos, în ambele sensuri. El are rolul special al revelării lui Dumnezeu Tatăl şi al mântuirii oamenilor restabilind comuniunea omului cu Dumnezeu. În Hristos, Dumnezeu ni se descoperă, ne vorbeşte şi ni se dăruieşte pentru a-1 cunoaşte şi a ne face asemenea Lui: vom fi asemenea Lui, fiindcă $\hat{I} l$ vom vedea cum este (I In. 3, 2).

Iisus Hristos, Dumnezeu-Omul, Cuvântul lui Dumnezeu întrupat, este Învăţătorul Suprem Care ne grăieşte în cuvinte omeneşti descoperindu-ne tainele mântuirii. El este

5 Iustin Popovici, Biserica Ortodoxă şi ecumenismul, trad. de Adrian Tănăsescu, Mănăstirea Sfinţii Arhangheli Petru Vodă, 2002, p. 9.

${ }^{6}$ Sfântul Ioan Damaschin, Dogmatica, III, 1, trad. de Dumitru Fecioru, ediţia a II-a, Bucureşti, Edit. Scripta, 1993, p. 96.

7 Dumitru Stăniloae, Iisus Hristos sau restaurarea omului, ediţia a II-a, Craiova, Edit. Omniscop, 1993, p. 81-87. 
„chipul lui Dumnezeu celui nevăzut, mai întâi născut decât toată făptura. Pentru că întru El au fost făcute toate, cele din ceruri şi cele de pe pământ, cele văzute, şi cele nevăzute, fie tronuri, fie domnii, fie începătorii, fie stăpânii. Toate s-au făcut prin El şi pentru El. El este mai înainte decât toate şi toate prin El sunt aşezate" (Col. 1, 15-17).

Ca unul prin Care şi pentru Care s-au făcut toate, El ne descoperă gândul lui Dumnezeu cu privire la om, şi anume de a ajunge la asemănarea cu Dumnezeu, şi îi conduce pe toţi cei care vor să-I urmeze la sfinţenie, dovedindu-se prin aceasta a fi Pedagogul Suprem, Pedagogul prin excelenţă.

Clement al Alexandriei, autorul primei schiţe a unei pedagogii creştine autonome şi închegate ${ }^{8}$, arată că Logosul întrupat este Protrepticul care, într-o primă fază, îndeamnă omul la mântuire, dar este şi Pedagogul care educă pasiunile şi acţiunile omului, precum şi Învăţătorul care aduce cunoaşterea desăvârşită, mântuitoare: Străduindu-Se deci să ne desăvârşească printr-o urcare treptată la mântuire, Logosul, Care în tot ce face e iubitor de oameni, foloseşte un program frumos, bine alcătuit, spre a ne da o educaţie cu rezultate bune: mai întâi ne îndeamnă (spre convertire), apoi ne educă şi în cele din urmă ne învaţă ${ }^{9}$.

Mântuitorul Iisus Hristos a dus la desăvârşire chipul învăţătorului împreunând cuvântul cu dragostea. Orice lucrare învăţătorească nu constă numai în împărtăşirea de cunoştinţe ci trebuie să vină din dragoste şi să trezească dragostea învăţăcelului. Mântuitorul Iisus Hristos a dus această dăruire de sine din dragoste până la nivelul suprem, jertfindu-Se pentru noi şi arătând astfel valoarea deosebită a învăţăturii Sale.

Învăţătura Sa nu este una obişnuită, omenească, ci este o învăţătură dumnezeiască - Invăţătura Mea nu este a mea ci a Celui ce M-a trimis (In. 7, 16) -, o învăţătură nouă şi cu putere (Mc. 1, 27, Lc. 4, 32) spre viaţa veşnică: cuvintele pe care vi le-am spus sunt duh

\footnotetext{
${ }^{8}$ Ernst Lichtenstein, op. cit., p. 25, apud Cristina Benga, op. cit., p. 73.

${ }^{9}$ Clement Alexandrinul, Pedagogul, I, I, 3, traducere, note şi indici de D. Fecioru, col. „Părinţi şi Scriitori Bisericeşti”, vol. 4, Bucureşti, Edit. Institutului Biblic şi de Misiune al Bisericii Ortodoxe Române, 1982, p. 12.
} 
şi sunt viaţă (In. 6, 63). Hristos ne-a făcut cunoscută taina din veci ascunsă neamurilor (Col. 1, 26). El ne-a descoperit măreaţa taină a Sfintei Treimi şi anume că Absolutul este personal, dar El nu este o singură persoană ci trei Persoane de o fiinţă unite prin iubire. Ni L-a descoperit pe Dumnezeu ca Sfânta Treime, structura supremei iubiri" ${ }^{10}$. Prin credinţa în acest Dumnezeu al iubirii, răspunzând chemării Lui prin iubire, ne unim cu El şi intrăm în Împărăţia cea fără de început, păstrându-ne existenţa noastră personală. În acelaşi timp Hristos ne-a arătat, în mod extraordinar de concret, omul în întâiul său chip şi în asemănare cu Dumnezeu ${ }^{11}$.

El nu demonstrează prin raţionamente, ci afirmă învăţătura Sa şi Se afirmă pe Sine cerând credinţă în cuvântul şi Persoana Sa, identificându-Se cu învăţătura Sa. Învăţătura Lui este revelaţia culminantă despre Dumnezeu şi despre om întrucât El Însuşi este ca Persoană această revelaţie. Noi învăţăm privind la Persoana Lui şi putem păşi pe urmele Lui stând în legătură cu El: Învăţaţi-vă de la Mine, că sunt blând şi smerit cu inima şi veţi găsi odihnă sufletelor voastre (Mt. 11, 29). El este modelul ultim al omenirii şi, unindu-ne cu El În Trupul Său tainic, Biserica, aflăm desăvârşirea, adică asemănarea cu Dumnezeu.

\section{Biserica - şcoala care ne educă spre viață veşnică în sfințenie}

Biserica este Trupul tainic al lui Hristos (Rom. 12, 4-5; I Cor. $12,13 ; 27)$ extins în umanitate, este viaţa dumnezeiască extinsă din trupul Său în oamenii care au crezut în El şi au răspuns chemării Lui, murind şi înviind împreună cu El în Botez (Rom. 6, 4). Biserica este aşadar viaţa nouă cu Hristos şi în Hristos condusă de Duhul Sfânt ${ }^{12}$. Prin Biserică, Trupul Său Dumnezeu-omenesc, Domnul a unit

10 Dumitru Stăniloae, Teologia Dogmatică Ortodoxă, vol. I, ediţia a II-a, Bucureşti, Edit. Institutului Biblic şi de Misiune al Bisericii Ortodoxe Române, 1996, p. 195.

${ }^{11}$ Arhimandritul Sofronie, Vom vedea pe Dumnezeu precum este, traducere din limba rusă de Ierom. Rafail (Noica), Bucureşti, Edit. Sophia, 2005, p. 97.

12 Serghei Bulgakov, Ortodoxia, trad. de Nicolae Grosu, Bucureşti, Edit. Paideia, 1994, p. 7. 
îngerii, oamenii şi toate făpturile zidite de Dumnezeu într-un organism veşnic viu. Astfel Biserica este plinirea Celui ce plineşte toate întru toţi (Efes. 1, 23), adică a lui Hristos, Dumnezeu-Omul, Care ca Dumnezeu plineşte toate întru toţi, iar ca om şi Arhiereu veşnic ne dă nouă, oamenilor, a trăi această plinire în Biserică, cu ajutorul Sfintelor Taine şi sfintelor fapte bune. În Biserică Dumnezeu ne-a blagoslovit, cu adevărat, cu toată blagoslovenia duhovnicească (Efes. 1, 3), în ea ne-a dat toate mijloacele pentru o viaţă sfântă şi fără prihană înaintea lui Dumnezeu (Efes. 1,4), în ea ne înfiază prin Fiul Său cel Unul-Născut (Efes. 1, 5-8), în ea ne-a descoperit taina cea veşnică a voii Sale (Efes. 1, 9), în ea a unit timpul cu veşnicia (Efes. 1, 10) şi a făcut cu putinţă întru-creştinarea şi în-creştinarea tuturor fiinţelor şi făpturilor, întru-duhovnicirea şi în-duhovnicirea lor, întru-treimificarea şi în-treimificarea lor (Efes. 1, 13-18). Pentru toate aceste temeiuri Biserica alcătuiește cea mai mare şi mai sfântă Taină a lui Dumnezeu din toate lumile ${ }^{13}$.

Biserica este un dar dumnezeiesc, o realitate eshatologică, pentru că funcţia ei principală este să manifeste şi să actualizeze în această lume eshatonul, realitatea finală a mântuirii - Împărăţia lui Dumnezeu. În acelaşi timp este răspunsul omenesc la darul dumnezeiesc, este creştere în credinţă, în dragoste, în cunoaştere şi comuniune $^{14}$. Numai în Biserică se descoperă taina lui Dumnezeu, a lucrării Sale, a iubirii Sale; numai în Biserică este posibilă creşterea în credinţă şi cunoaştere ${ }^{15}$. Biserica are misiunea de a mărturisi iubirea nesfârşită a lui Dumnezeu ca iubire trinitară, a revela misterul Treimii care iese din transcendenţa Sa în actul creării lumii şi care

${ }^{13}$ Iustin Popovici, op. cit., p. 10.

14 Alexander Schmemann, The Missionary Imperative în Church, World, Mission. Reflections on Orthodoxy In the West, Crestwood, St. Vladimir's Seminary Press, 1979, p. 211.

${ }^{15}$ Această afirmaţie sintetizează experienţa teologică şi eclezială a Pr. Serghei Bulgakov, apud Boris Bobrinskoy, Taina Bisericii, trad. de Vasile Manea, Cluj Napoca, Edit. Patmos, 2002, p. 37. 
zideşte pe om după chipul Său trinitar pentru a-l face să participe la viaţa dumnezeiască ${ }^{16}$.

Biserica este locuinţă a Duhului Sfânt care a transportat prin veacurile pline de tot felul de tulburări preţioasa comoară a Adevărului revelat de Dumnezeu. Misiunea Bisericii este de a-i duce pe fiii ei în tărâmul Fiinţării Dumnezeieşti ${ }^{17}$, de a uni organic şi personal pe toţi credincioşii ei cu Persoana lui Hristos, personalitatea lor să devină personalitate în Hristos şi prin Hristos, în ei să trăiască nu ei înşişi ci Hristos să trăiască în ei (Gal. 2, 20). Misiunea Bisericii este de a întări mădularele ei în nemurire şi veşnicie, făcându-le părtaşe firii lui Dumnezeu (II Pt. 1, 4), de a crea în fiecare membru al ei convingerea că starea normală a personalităţii umane o constituie nemurirea şi veşnicia, convingerea că omul este un călător care prin moarte şi temporalitate înaintează spre nemurire şi veşnicie ${ }^{18}$.

Mântuitorul aşadar Îşi continuă în Biserică, Trupul Său, cu puterea Duhului Sfânt, lucrarea de educare a omului. Biserica poate fi numită în acest sens şcoală, o şcoală în care Hristos nu ne învaţă o înţelepciune omenească ci descoperă oamenilor şi îngerilor inţelepciunea lui Dumnezeu cea de multe feluri (Efes. 3, 10), iconomia tainei celei din veci ascunse în Dumnezeu (Efes. 3, 9), o şcoală în care suntem educaţi spre a ajunge la asemănarea cu Dumnezeu, spre îndumnezeire, spre participare ontologică la însăşi viaţa lui Dumnezeu, ca unire prin har a existenţei omeneşti cu cea dumnezeiască $\breve{1}^{19}$. Dumnezeu-Omul Hristos nu ne arată doar ţinta ci ne oferă, în Biserică, mijloacele şi puterea de a atinge desăvârşirea. Biserica este acel minunat organism divino-uman în care, prin conlucrarea harului dumnezeiesc cu lucrarea liberă a omului, se face

${ }^{16}$ Boris Bobrinskoy, Mesajul Ortodoxiei la acest sfârşit de mileniu, trad. de I. A. Forga în „Vestitorul Ortodoxiei”, an XI, nr. 237-238, decembrie, 1999, p. 5. ${ }^{17}$ Arhimandritul Sofronie, op. cit., p. 136.

${ }^{18}$ Iustin Popovici, Omul şi Dumnezeul-Om. Abisurile şi culmile filozofiei, studiu introductiv şi traducere de Ioan Ică şi Ioan I. Ică jr., Sibiu, Edit. Deisis, 1997, p. 74-75.

${ }^{19}$ John Breck, Puterea cuvântului în Biserica dreptmăritoare, trad. de Monica E. Herghelegiu, Bucureşti, Edit. Institutului Biblic şi de Misiune al Bisericii Ortodoxce Române, 1999, p. 146. 
nemuritor şi se îndumnezeieşte omul întreg şi tot ce-i omenesc afară de păcat ${ }^{20}$.

În Biserică sfinţiţii slujitori, prin harul primit de la Hristos, ne educă spre a ajunge cu toţii la unitatea credinţei şi a cunoaşterii Fiului lui Dumnezeu, la starea bărbatului desăvârşit, la măsura vârstei deplinătăţii lui Hristos (Efes. 4, 13). La unitatea credinţei şi a cunoaşterii lui Hristos se ajunge numai în unire cu toţi sfinţii (Efes. 3, 18), numai prin viaţa sobornicească cu toţi sfinţii, sub călăuzirea Sfinţilor Apostoli, Proroci, Evanghelişti, Păstori, Părinţi, Învăţători (Efes. 4, 11). Pe aceştia îi călăuzeşte şi îi poartă în chipul cel mai sfânt Duhul Sfânt, din ziua Cincizecimii şi mai departe, de-a lungul veacurilor, până la înfricoşata judecată. In Duhul Sfânt şi de la Duhul Sfânt este unitatea credinţei şi cunoaşterii Fiului lui Dumnezeu, a Domnului nostru Iisus Hristos ${ }^{21}$.

Unirea credinţei şi a cunoaşterii Fiului lui Dumnezeu nu înseamnă doar acumularea de cunoştinţe despre Hristos ci presupune transformarea omului, se împlineşte în ajungerea fiecăruia la starea bărbatului desăvârşit, la măsura vârstei deplinătăţii lui Hristos (Efes. 4, 13). După cum remarca Sfântul Nicodim Aghioritul, prin cunoaşterea Fiului lui Dumnezeu Sfântul Pavel înţelege cunoaşterea suprafirească a Fiului lui Dumnezeu enipostaziat în inimă prin dumnezeiasca luminare şi proslăvire care se dă multor desăvârşiţi ce s-au curăţit de patimile trupeşti şi sufleteşti, lucru la care îi voieşte pe toţi creştinii să ajungă ${ }^{22}$ : Pe El noi Îl vestim, sfătuind pe orice om şi învăţând pe orice om, întru toată inţelepciunea, ca să înfăţişăm pe tot omul, desăvârşit, în Hristos Iisus (Col. 1, 28).

Biserica ne dăruieşte o educaţie duhovnicească, nestricăcioasă, pentru veşnica şi fericita împreună-împărăţirea omului cu Dumnezeu şi cu sfinţii Săi în ceruri. Dar, după cum ne învaţă Sfântul Ioan din Kronştadt, pentru aşa ceva oamenii trebuie mai întâi pregătiţi, luminaţi, curăţiţi, schimbaţi cu bună schimbare,

\footnotetext{
${ }^{20}$ Iustin Popovici, Omul şi Dumnezeul-Om, p. 128.

${ }^{21}$ Idem, Biserica Ortodoxă şi ecumenismul, p. 21

22 apud Hierotheos Vlachos, Cugetul Bisericii Ortodoxe, trad. de Constantin Făgeţan, Edit. Sophia, Bucureşti, 2000, p. 152.
} 
înnoiţi, învăţaţi nestricăciunea, viaţa fără de vicii, blândețea, smerenia, curăţia, ascultarea, curajul, răbdarea, înfrânarea, iubirea nefăţarnică, milostenia, nădejdea nezdruncinată, credinţa neșovăitoare, lipsa de avuții, comuniunea bunurilor părinteşti materiale şi duhovniceşti ${ }^{23}$. Numai în Biserică, ajungând la unitatea credinţei şi a cunoaşterii Fiului lui Dumnezeu (Efes. 4, 13), omul dobândeşte adevărata cunoaştere de sine despre originea sa, despre crearea sa după chipul lui Dumnezeu, despre căderea şi stricăciunea sa prin păcat, despre restaurarea, sfinţirea, înnoirea şi împăcarea cu Făcătorul şi Legiuitorul, cu Proniatorul şi Mântuitorul Său ${ }^{24}$.

Educaţia pe care o face Biserica urmăreşte să-i ajute pe credincioşi să înţeleagă împreună cu toţi sfinţii care este lărgimea şi lungimea înălţimea şi adâncimea, să cunoască iubirea lui Hristos cea mai presus de cunoştinţă ca să se umple de toată plinătatea lui Dumnezeu (Efes. 3, 18-19). Să fi umplut cu toată plinătatea lui Dumnezeu în Biserică prin puterea Sfântului Duh nu înseamnă doar o acumulare de cunoştinţe despre Dumnezeu, om şi lume. În acelaşi timp înseamnă dobândirea virtuţii, dobândirea sănătăţii sufletului şi trupului, a iluminării autentice şi a vieţii veşnice ${ }^{25}$.

Sfântul Ioan din Kronştadt, Liturghia: cerul pe pământ. Cugetări mistice despre Biserică şi Cultul divin ortodox, trad. de Boris Buzilă, Edit. Deisis, Sibiu, 1996, p. 90.

${ }^{24}$ Sfântul Ioan din Kronştadt, op. cit., p. 108.

${ }^{25}$ Amfilohie (Radovic), Metropolitan of Montenegro and Coastlands, Church, Liturgy, Education, paper delivered to the participants of B.O.Y.A. Conference "The Problem of Cathesesis in the Churches on the Balkans", Chania, Crete, Greece, 2-7.09.1997, p. 2. 


\section{Concluzii}

Educaţia pe care statul secular o propune tinerilor este o educaţie centrată pe lumea aceasta, o educaţie ce urmăreşte în primul rând transmiterea cunoştinţelor şi a abilităţilor necesare integrării în societate. În acelaşi timp mass-media se impune tot mai mult ca un educator cu mare impact asupra tinerilor dar, din nefericire, un educator care, de obicei, promovează o adevărată cultură a morţii, retezând perspectiva veşniciei şi incitând la păcat prin cultivarea idolilor lumii căzute: banul, plăcerea şi puterea.

În Biserica însă se cultivă viaţa, omul primește prin lucrarea harului Duhului Sfânt puterea de a depăşi limitele acestei vieţi trecătoare, de a învinge moartea, de a se sfinţi ajungând la asemănarea cu Dumnezeu. De aceea educaţia Bisericii este în mod esenţial diferită de orice educaţie profană care se adresează omului căzut fără a-i da puterea de a-şi depăşi condiţia de om muritor, este o educaţie pentru viaţa veşnică în Împărăţia lui Dumnezeu.

În demersul educaţional al Bisericii anii copilăriei şi ai tinereții au o importanţă aparte, atunci punându-se bazele întregii orientări a vieţii omului. Educaţia tinerilor în Biserică, ca expresie a lucrării lui Dumnezeu de educare a omului începută la crearea lumii şi care culminează în întruparea Fiului lui Dumnezeu, se realizează prin unirea lor cu Hristos în Sfintele Taine şi împlinirea poruncilor lui Dumnezeu, adică prin trăirea unei vieţi duhovniceşti. Angajarea tinerilor în trăirea unei vieţi duhovniceşti trebuie să fie finalitatea atât a educaţiei creştine din familie ${ }^{26}$ cât şi a orelor de Religie, a lecţiilor

${ }^{26}$ În prezent există o destul de bogată bibliografie, în limba română, de lucrări cu privire la modalitatea concretă de realizare a educaţiei creştin ortodoxe a copiilor în familie: Irineu, episcop de Ekaterinburg şi Irbit, Educaţia religioasă. Învăţături pentru copii şi tineri, traducător Dana Potlog, Bucureşti, Edit. Sophia, 2002; Simion Kraipopoulos, Părinţi şi copii. Abordare teologică, duhovnicească şi psihologică, trad. de Constantin Coman şi Garoafa Coman, Bucureşti, Edit. Bizantină, 2005; Maica Magdalena, Sfaturi pentru o educaţie ortodoxă a copiilor de azi, Sibiu, Editura Deisis, 2000; Maica Magdalena, Cum să comunicăm copiilor credinţa ortodoxă. Convorbiri, reflecţii şi alte sfaturi, trad. de Cristian Pop şi Ioan I. Ică jr, Sibiu; Edit. Deisis, 2002; Sfântul 
de catehism şi a tuturor activităţilor pe care Biserica le organizează pentru tineri. Educaţia tinerilor în Biserică nu se rezumă aşadar la slujbe şi la activităţile desfăşurate în locaşul bisericii, ci această educaţie, începând de la cea oferită copiilor în familie şi la şcoală până la catehizarea în biserică, trebuie împlinită de către membrii Bisericii cu conştiinţa că sunt mădulare ale lui Hristos prin care Hristos lucrează continuându-şi lucrarea Sa pedagogică în lume.

Aşadar Biserica, prin diversele slujiri ale membrilor ei, poate fi pe bună dreptate văzută ca o şcoală care, în mod continuu, îi educă pe toţi, tineri şi adulţi, spre viaţă veşnică în sfinţenie, în sensul imbrăcării în omul cel nou, cel zidit după Dumnezeu în dreptatea şi sfinţenia adevărului (Efes. 4, 25). Obiectivul unei astfel de educaţii este ca, cunoscând iubirea lui Hristos, cea mai presus de cunoştinţă (Efes 3, 19) şi ţinând adevărul, în iubire, în toate să creştem întru El care este capul, Hristos (Efes. 4, 15).

Vladimir, Mitropolitul Kievului, Despre educaţie, trad. de Xenia şi Adrian Tănăsescu Vlas, Bucureşti, Editura Sophia, 2006; Elisabeth White, Tărâmul minunilor. Cum să sădim virtuţile creştine ortodoxe în inimile copiilor noştri, trad. de Luminiţa Irina Niculescu, Bucureşti, Edit. Sophia, 2007; etc. 